\title{
KEEFEKTIFAN PENGGUNAAN MEDIA SESUNGGUHNYA DALAM PENYULUHAN PENGENDALIAN HAMA DAN PENYAKIT PADA TANAMAN JAGUNG DI KABUPATEN LANGKAT PROVINSI SUMATERA UTARA
}

\author{
Mukhlis Yahya, Herawaty, Misiyem, Eka Widya Lestary \\ Politeknik Pembangunan Pertanian Medan, Jl. Binjai Km. 10 Tromol Pos 18 2002, Medan
}

Koresponden Email : misiyem05@gmail.com

\begin{abstract}
Abstrak
Kabupaten Langkat merupakan daerah potensial dalam melaksanakan usaha tani budidaya jagung, namun petani sering menemukan kendala terkait dengan hama dan penyakit yang menyebabkan produksi jagung rendah. Oleh karena itu penyuluh memberikan penyuluhan pengendalian hama dan penyakit pada tanaman jagung dengan menggunakan media sesungguhnya. Kegiatan penelitian bertujuan: 1) Untuk mengetahui tingkat efektivitas penggunaan media sesungguhnya dalam penyuluhan pengendalian hama dan penyakit pada tanaman jagung di Kabupaten Langkat. 2) Untuk mengetahui faktor-faktor yang mempengaruhi efektivitas penggunaan media sesungguhnya dalam penyuluhan pengendalian hama dan penyakit pada tanaman jagung di Kabupaten Langkat. Metode penelitian yang digunakan adalah survey. Pengambilan sampel petani dilakukan dengan menggunakan metode acak sederhana (simple random sampling) dari populasi. Instrumen yang digunakan berupa kuesioner yang berisi pernyataan mengenai keefektifan dan faktor yang mempengaruhi penggunaan media sesungguhnya. Kuesioner yang digunakan terlebih dahulu diuji validitas reliabilitasnya. Metode analisis data yang digunakan yaitu dengan menghitung persentase perolehan skor dan analisis regresi linear berganda. Hasil penelitian menunjukkan bahwa tingkat efektivitas penggunaan media sesungguhnya dalam penyuluhan pengendalian hama dan penyakit pada tanaman jagung tergolong sangat efektif yaitu sebesar $86,14 \%$. Berdasarkan pengujian analisis regresi linear berganda yang dilakukan, terdapat tiga faktor yang mempengaruhi efektivitas penggunaan media sesungguhnya dalam penyuluhan pengendalian hama dan penyakit pada tanaman di Kabupaten Langkat yaitu faktor Komunikasi (X1), Karakteristik Petani (X2) dan Biaya (X5) sebesar 88\% sedangkan sisanya dipengaruhi oleh faktor lain yang tidak diteliti dalam penelitian ini.
\end{abstract}

\section{Kata Kunci: Keefektifan Media Sesungguhnya, Hama dan Penyakit Jagung}

\begin{abstract}
Langkat Regency is a potential area in carrying out corn cultivation but farmers often encounter obstacles related to pests and diseases that cause low corn production. Extension officers provide counseling on pest and disease control in corn plants using real media. The research activities aimed: 1) To determine the level of effectiveness of the actual use of media in counseling pest and disease control on corn plants in Langkat Regency. 2) To find out the factors that affect the effectiveness of the actual use of media in counseling on pest and disease control on corn plants in Langkat Regency. The research method used is a survey, farmer sampling is done using simple random sampling from the population. The instrument used is a questionnaire containing statements about the effectiveness and factors that influence the actual use of media. The questionnaire used was first tested for its validity and reliability. The data analysis method used is to calculate the percentage of score acquisition and multiple linear regression analysis. The results showed that the level of effectiveness of the actual use of media in counseling pest and disease control on corn plants was classified as very effective, namely $86.14 \%$. Based on the multiple linear regression analysis conducted, there are three factors that influence the effectiveness of the actual use of media in pest and disease control counseling in plants in Langkat Regency, namely the Communication factor (X1), Farmer Characteristics (X2) and Cost (X5) of $88 \%$ while the rest is influenced by other factors not examined in this study.
\end{abstract}

Keywords: Effectiveness of Real Media Use, Corn Pests and Diseases 


\section{PENDAHULUAN}

Sistem penyuluhan pertanian merupakan seluruh rangkaian pengembangan kemampuan, pengetahuan, keterampilan serta sikap pelaku utama (pelaku kegiatan pertanian) dan pelaku usaha melalui penyuluhan. Penyuluhan Pertanian adalah suatu proses pembelajaran bagi pelaku utama (pelaku kegiatan pertanian) serta pelaku usaha agar mereka mau dan mampu menolong dan mengorganisasikan dirinya dalam mengakses informasi pasar, teknologi, permodalan, dan sumberdaya lainnya, sebagai upaya untuk meningkatkan produktivitas, efisiensi usaha, pendapatan, dan kesejahteraannya, serta meningkatkan kesadaran dalam pelestarian fungsi lingkungan hidup.

Di dalam penyuluhan, media penyuluhan sangat penting untuk membantu kelancaran pelaksanaan penyuluhan maupun untuk memperjelas materi yang disampaikan agar mudah diingat dan dipahami oleh masyarakat penerima manfaatnya. Beragamnya media memiliki karakteristik yang berbeda pula. Karena itu, untuk setiap tujuan yang berbeda diperlukan media yang berbeda pula. Dalam kaitannya dengan penyelenggaraan penyuluhan maupun pembelajaran penggunaan media sebagai saluran penyampaian pesan sangat penting.

Bentuk-bentuk media penyuluhan itu sendiri terdapat berbagai macam bentuk. Klasifikasi menurut pemakaiannya ada 4 (empat) macam bentuk media yang digunakan, yaitu media audio, media visual, media audio visual dan media sesungguhnya. Dalam penelitian ini yang akan dikaji adalah penggunaan media sesungguhnya dalam kegiatan penyuluhan pertanian tentang pengendalian hama dan penyakit jagung Kabupaten Langkat.

Kabupaten Langkat merupakan salah satu daerah produsen jagung dengan luas lahan 6.051 Ha [1]. Wilayah sentra jagung di Kabupaten Langkat tersebar di beberapa kecamatan. Di dalam melaksanakan usaha tani budidaya jagung, petani sering menemukan kendala terkait dengan hama dan penyakit yang menyebabkan produksi jagung rendah. Untuk itu penyuluh pertanian sebagai pendamping petani telah memberikan penyuluhan pengendalian hama dan penyakit pada tanaman jagung. Dalam kegiatan penyuluhan tersebut, penyuluh telah menggunakan media penyuluhan sesungguhnya. Penggunaan media sesungguhnya oleh penyuluh pertanian dianggap dapat memudahkan petani menerima pesan penyuluhan. Harapannya dengan media sesungguhnya petani dapat melihat secara langsung contoh hama dan penyakit yang menyerang tanaman jagung, sehingga kegiatan penyuluhan menjadi efektif. Hal ini sejalan dengan penelitian [2], bahwa penggunaan alat peraga berpengaruh positif untuk memudahkan penyampaian materi. Kegiatan penyuluhan pengendalian hama dan penyait telah dilaksanakan, tetapi kegiatan evaluasi terhadap pelaksanaan belum dilakukan. Belum diketahui efektifitas penggunaan media penyuluhan sesungguhnya pada penyuluhan pengendalian hama dan penyakit jagung di kabupaten langkat. Padahal pengetahuan tentang efektifiitas ini, sangat penting untuk memperbaiki kegiatan penyuluhan dan manfaatnya untuk mengatasi rendah produksi jgaung akibat hama dan penyakit.

Berdasarkan uraian diatas, perlu dilakukan penelitian yang bertujuan untuk mengkaji efektifitas penggunaan media sesungguhnya dan faktor-faktor yang mempengaruhi penggunaan media sesungguhnya dalam penyuluhan pengendalian hama dann penyakit jagung di Kabupaten Langkat.

\section{Waktu dan Tempat}

Penelitian telah dilaksanakan pada Bulan Maret s/d Desember 2020 di Kabupaten Langkat Provinsi Sumatera Utara. Berdasarkan luas dan lokasi kegiatan penyuluhan, maka sampel lokasi-lokasi penelitian adalah Kecamatan Sei Bingai, Kecamatan Stabat, Kecamatan Selesai dan Kecamatan Serapit.

\section{Metode Penelitian}

Metode penelitian yang digunakan adalah metode survei. Metode penelitian adalah penelitian yang dilakukan dengan cara menyusun daftar pertanyaan/pernyataan yang diajukan pada responden, digunakan untuk meneliti gejala suatu kelompok atau perilaku individu, dan penggalian data melalui kuesioner dan wawancara [3].

\section{Metode Pengambilan Sampel}

Pengambilan sampel petani dilakukan dengan menggunakan metode acak sederhana (simple random sampling). Sampel dalam penelitian ini adalah petani yang melakukan budidaya tanaman jagung dan mengikuti kegiatan penyuluh pertanian dengan 
menggunakan media sesungguhnya. Dari 4 (empat) kecamatan lokasi penelitian telah diperoleh populasi sebanyak 180 orang dan dengan menggunakan rumus Yamane pada tingkat presisi $10 \%$, telah ditetapkan sebanyak 64 sampel. Penetapan jumlah sampel untuk tiap kecamatan didasarkan pada komposisi banyaknya populasi dari tiap kecamatan. Berdasarkan ketentuan tersebut, telah ditetapkan jumlah sampel dari kecamatan Sei Bingai sebanyak 15 orang, kecamatan Stabat 15 orang, kecamatan Selesai 15 orang, dan kecamatan Serapit 19 orang.

\section{Kerangka Pikir}

Adapun kerangka pikir penelitian ini adalah seperti disajikan pada Gambar 1.

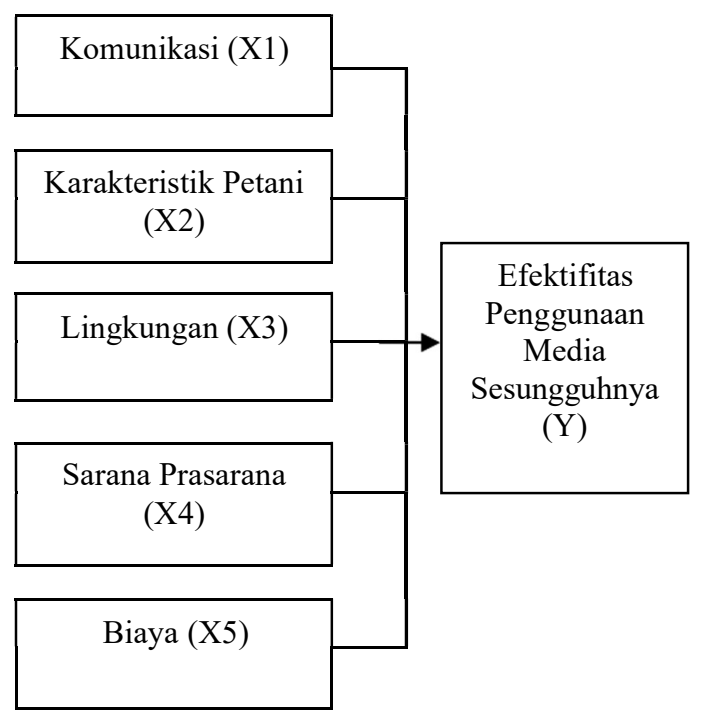

Gambar 1. Kerangka Pikir

\section{Data dan Teknik Pengumpulan Data}

Sumber data yang digunakan dalam mendukung penelitian yaitu data primer dan data sekunder. Data primer diperoleh dari wawancara langsung kepada petani, melalui daftar pertanyaan yang telah disiapkan. Selain itu, data primer diperoleh dari Penyuluh Pertanian dan Kepala BPP. Data sekunder yaitu data yang diperoleh dari instansi terkait, buku, catatan, laporan yang ada kaitannya dengan penelitian ini serta diperlukan untuk melengkapi data primer.

Data yang diperlukan dalam penelitian ini adalah pendapat petani tentang efektifitas penggunaan media sesungguhnya $(\mathrm{Y})$ dalam kegiatan penyuluhan pengendalian hama dan penyakit di kabupaten langkat. Selanjutnya sesuai dengan pernyataan [4] dan [5], bahwa yang dapat mempengaruhi efektivitas penggunaan media sesungguhnya adalah faktorfaktor yang mempengaruhi efektifitas penggunaan media seungguhnya dalam penyuluhan, yaitu Komunikasi, Karakteristik petani, Lingkungan, Sarana dan Prasarana, dan Biaya. Sehingga data yang dikumpulkan adalah Komunikasi (X1), Karakteristik petani (X2), Lingkungan (X3), Sarana dan Prasarana (X4), dan Biaya (X5)

Teknik pengumpulan data yang dilakukan dalam pelaksanaan penelitian ini menggunakan kuesioner sebagai alat pengumpul data [6].

\section{Pengukuran Variabel}

Pengukuran variable terikat dalam penelitian ini menggunakan skala likert. Menurut [7] skala likert adalah sebagai skala dalam jenis data penelitian untuk mengukur sikap, pendapat, dan persepsi terhadap inidvidu atau kelompok terkait dengan fenomena sosial yang sedang menjadi subjek penelitian. Pada penelitian untuk mengukur Efektivitas Penggunaan Media sesungguhnya menggunakan skala likert skor pernyataan positif seperti yang disajikan pada Tabel 1.

Tabel. 1. Pengukuran Skala Likert

\begin{tabular}{lc}
\hline Pernyataan & Skala Likert \\
\hline Sangat Tidak Efektif(STE) & 1 \\
Tidak Efektif(TE) & 2 \\
Cukup Efektif (CE) & 3 \\
Efektif(E), & 4 \\
Sangat Efektif (SE) & $\underline{5}$ \\
\hline
\end{tabular}

\section{Analisis Data}

Kuesioner yang digunakan telah uji validitas dan reliabilitasnya. Validitas digunakan untuk melihat kelayakan butir-butir pertanyaan suatu variabel dalam kuesioner dan dikatakan valid apabila nilai $r$ hitung $>\mathrm{t}$-tabel. Uji reliabilitas dimaksudkan untuk menilai kestabilan ukuran dan konsistensi responden dalam menjawab kuesioner dan dikatakan reliabel apabila nilai Alpha Cronbach hitung > 0,6 [8].

Untuk menilai tingkat efektifitas penggunaan media sesungguhnya digunakan rumus sebagai berikut:

$$
\begin{aligned}
& \text { Tingkat Efektivifitas } \\
& =\frac{\text { Skor yang diperoleh }}{\text { Skor Maksimal }} \times 100 \% \text {...Pers (1) }
\end{aligned}
$$


Dengan kriteria interprestasi skor sebagai berikut:

- $0 \%-20 \%=$ Sangat tidak efektif

- $21 \%-40 \%=$ Tidak efektif

- $41 \%-60 \%=$ Cukup efektif

- $61 \%-80 \%=$ Efektif

- $81 \%-100 \%=$ Sangat efektif

Selanjutnya untuk mengkaji faktor-faktor yang mempengaruhi keefektifan media sesungguhnya, digunakan analisis regresi linear berganda. Adapun rumus yang digunakan yaitu [3]:

$Y=\alpha+\beta 1 X 1+\beta 2 X 2+\beta 3 X 3+\beta 4 X 4$

$$
+\beta 5 X 5 \ldots \text {...Pers (2) }
$$

Keterangan:

$Y=$ Tingkat keefektifan penyuluhan

$\alpha=$ Konstanta

$\beta=$ Koefisien regresi

$\mathrm{X}_{1}=$ Komunikasi

$\mathrm{X}_{2}=$ Karakteristik Petani

$\mathrm{X}_{3}=$ Lingkungan

$\mathrm{X}_{4}=$ Sarana Prasarana

$\mathrm{X}_{5}=$ Biaya

\section{HASIL DAN PEMBAHASAN}

\section{Karakteristik Petani Responden}

Karakteristik petani jagung yang dijadikan sebagai responden sebanyak 64 orang dijelaskan sebagai berikut:

\section{Luas lahan}

Karakteristik petani jagung yang menjadi responden berdasarkan luas lahan yang dikelola disajikan pada Tabel 1. Pada Tabel 1, dapat dilihat bahwa pengusahaan lahan jagung oleh petani berkisar antara $\leq 1$ Ha sampai dengan $\geq 1$ Ha.

Tabel 1. Luas Lahan Petani Responden.

\begin{tabular}{ccc}
\hline $\begin{array}{c}\text { Luas Usahatani } \\
\text { (Ha) }\end{array}$ & $\begin{array}{c}\text { Jumlah Petani } \\
\text { (orang) }\end{array}$ & $\begin{array}{c}\text { Persentase } \\
(\%)\end{array}$ \\
\hline$\leq 1$ & 32 & 50 \\
$\geq 1$ & 32 & 50 \\
Jumlah & 64 & 100 \\
\hline
\end{tabular}

\section{Pendidikan}

Karakteristik petani responden berdasarkan tingkat pendidikan disajikan pada Tabel 2 . Berdasarkan data pada Tabel 2, petani responden berpendidikan SD berjumlah 5 orang $(7,8 \%)$, berpendidikan SMP berjumlah 19 orang
(29,7\%), berpendidikan SMA berjumlah 36 orang $(56,2 \%)$, dan Perguruan Tinggi berjumlah 4 orang $(6,3 \%)$.

Tabel 2. Tingkat Pendidikan Petani Responden.

\begin{tabular}{lcc}
\hline $\begin{array}{c}\text { Tingkat } \\
\text { Pendidikan }\end{array}$ & $\begin{array}{c}\text { Jumlah Petani } \\
\text { (Orang) }\end{array}$ & $\begin{array}{c}\text { Persentase } \\
(\%)\end{array}$ \\
\hline SD & 5 & 7,8 \\
SLTP/SMP & 19 & 29,7 \\
SLTA/SMA & 36 & 56,2 \\
Perguruan & 4 & 6,3 \\
Tinggi & & \\
$\quad$ Jumlah & 64 & 100 \\
\hline
\end{tabular}

Umur

Umur petani juga berpengaruh kepada kapasitas atau kemampuan belajar petani. Semakin tinggi umur petani maka kapasitas belajar petani pun semakin rendah. Menurut [9] bahwa perkembangan kemampuan berpikir terjadi seiring dengan bertambahnya umur. Umur petani responden sangat berpengaruh terhadap efektivitas penggunaan media sesungguhnya dikarenakan tingkat pemahaman dan penerimaan informasi oleh petani berbedabeda. Semakin tua umur petani maka petani semakin berpengalaman sehingga petani dinilai akan lebih cermat dalam mengambil keputusan [10]. Karakteristik petani responden berdasarkan umur disajikan pada Tabel 3.

Tabel 3. Umur Petani Responden

\begin{tabular}{ccc}
\hline Umur (Thn) & $\begin{array}{c}\text { Jumlah Petani } \\
\text { (Orang) }\end{array}$ & $\begin{array}{c}\text { Persentase } \\
(\%)\end{array}$ \\
\hline $21-30$ & 4 & 6,25 \\
$31-40$ & 11 & 17,10 \\
$41-50$ & 21 & 32,80 \\
$51-60$ & 19 & 29,70 \\
$61-70$ & 9 & 14,15 \\
Jumlah & 64 & 100,00 \\
\hline
\end{tabular}

Berdasarkan Tabel 3 diketahui lebih banyak petani responden berada pada rentang umur 41 50 tahun, disusul oleh rentang umur $51-60$ tahun.

\section{Produktivitas Jagung}

Karakteristik petani responden berdasarkan produktivitas jagung disajikan pada Tabel 4 . Berdasarkan Tabel 4, dapat dilihat bahwa produktivitas jagung petani responden terbesar adalah $3,1-5$ ton/ha sebanyak 21 orang $(32,8 \%)$ dan $5,1-7$ ton/ha sebanyak 21 orang $(32,8 \%)$. 
Produktivitas tertinggi sebesar $7,1-9$ ton/ha ada sejumlah 14 petani $(21,9 \%)$, dan terendah dengan produktivitas $<3$ ton/ha ada sejumlah 8 petani $(12,5 \%)$. Berdasarkan data ini, dapat dikatakan bahwa rata-rata produktivitas jagung para petani masih rendah. Produktivitas dapat dipengaruhi oleh luas lahan petani responden, keterampilan petani dalam usaha budidaya tanaman jagung, dan tak luput dari peran bimbingan serta dukungan Penyuluh Pertanian Lapangan pada masing-masing kelompok tani.

Tabel 4. Hasil Produksi Tanaman Jagung Petani Responden

\begin{tabular}{ccc}
\hline $\begin{array}{c}\text { Hasil Produksi } \\
\text { (ton/ha) }\end{array}$ & $\begin{array}{c}\text { Jumlah Petani } \\
\text { (Orang) }\end{array}$ & $\begin{array}{c}\text { Persentase } \\
(\%)\end{array}$ \\
\hline$<3$ & 8 & 12,5 \\
$3,1-5$ & 21 & 32,8 \\
$5,1-7$ & 21 & 32,8 \\
$7,1-9$ & 14 & 21,9 \\
Jumlah & 64 & 100 \\
\hline
\end{tabular}

Efektivitas Penggunaan Media Sesungguhnya

Penyuluhan pengendalian hama dan penyakit pada tanaman jagung dengan menggunakan media sesungguhnya telah dilakukan. Pada penyuluhan pengendalian hama ulat tentara, media yang digunakan adalah tanaman jagung yang terserang daun tanaman jagung yang terserang hama ulat tentara (Gambar 2), insectisida, alat semprot. Pada penyuluhan pengendalian penyakit blast pada tanaman jagung, telah digunakan tanaman jagung yang terkena blast (Gambar 3), benih jagung, dan fungisida sebagai obatnya.

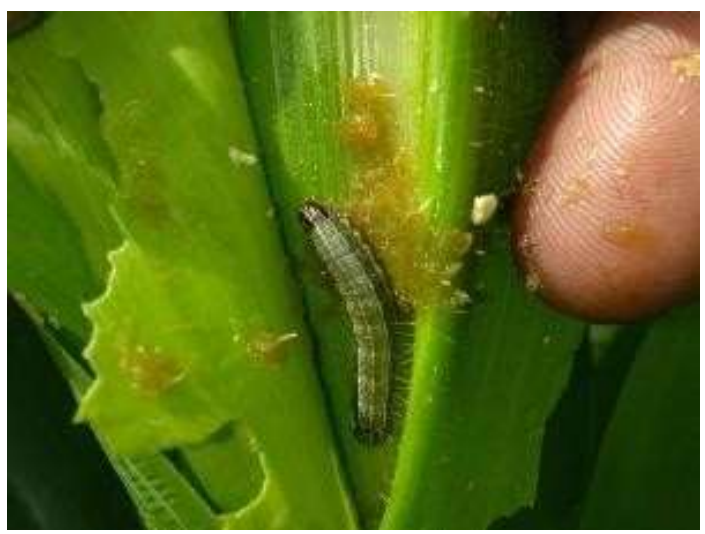

Gambar 2. Media Sesungguhnya Tanaman Jagung Terserang Hama Ulat Tentara

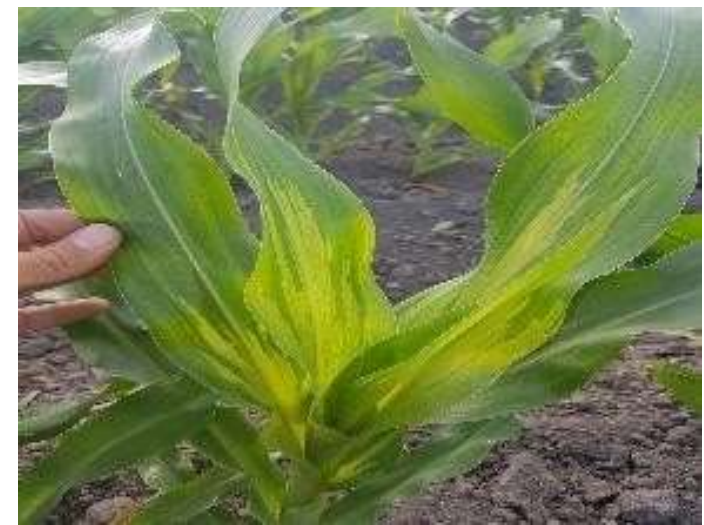

Gambar 3. Media Sesungguhnya Tanaman Jagung Terserang Penyakit Blast

Efektivitas penggunaan media sesungguhnya dalam penyuluhan pengendalian hama dan penyakit pada tanaman jagung di Kabupaten Langkat diukur dengan menggunakan Persamaan 1. Hasil pengukuran tingkat efektivitas penggunaan media sesungguhnya dalam penyuluhan pengendalian hama dan penyakit pada tanaman jagung di Kabupaten Langkat disajikan pada Tabel 5.

Tabel 5. Tingkat Efektivitas Penggunaan Media Sesungguhnya

\begin{tabular}{lc}
\hline Komponen Efektivitas & Hasil \\
\hline Skor Responden & 3.859 \\
Skor Maksimum & 4.480 \\
Tingkat Efektifitas (\%) & 86,14 \\
Tingkat Keefektifan & Sangat Efektif \\
\hline
\end{tabular}

Nilai tingkat keefektifan yang ada di Tabel 5, selanjutnya diplotkan pada garis kontinum seperti disajikan pada Gambar 4.

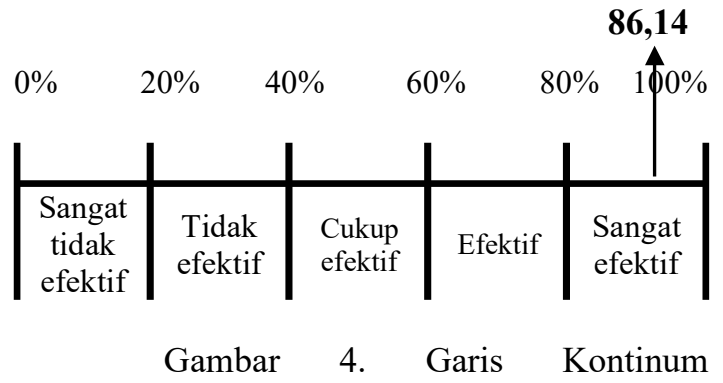

Berdasarkan data pada Tabel 5 diketahui bahwa efektivitas penggunaan media sesungguhnya dalam penyuluhan pengendalian hama dan penyakit pada tanaman jagung di Kabupaten Langkat tergolong sangat efektif 
yaitu $86,14 \%$. Kegiatan penyuluhan yang dilakukan oleh penyuluh pertanian mampu mencapai sasaran atau tujuan yang telah ditentukan sebelumnya. Hal ini dikarenakan penggunaan media sesungguhnya memberi pengalaman belajar secara langsung, dapat memperjelas informasi karena dapat dilihat secara, dapat menghindari kesalah pahaman dalam, dapat mempermudah penyampaian informasi, dapat mempermudah, dapat mengurangi penggunaan tulisan secara berlebihan, dapat menampilkan hama dan penyakit yang sulit ditangkap dengan mata, dapat memperlancar komunikasi, materi pelajaran tidak terbatas pada hama/penyakit saat penyuluhan, lebih berkualitas, proses belajar dapat berlangsung secara terus menerus dan berkelanjutan, lebih menarik perhatian petani, dapat menghemat, dan dapat membantu proses belajar secara aktif.

Pendapat [1] bahwa umur seseorang berkaitan dengan kapasitas dan efisiensi belajar mengajar, serta kemampuan dalam menerima dan mengadopsi suatu inovasi, serta kemampuan dalam meningkatkan produktivitas kerja dalam melakukan usahatani. Dengan digunakannya media langsung akan lebih mengefektifikan penyuluhan yang dilakukan. Seperti pendapat [11] bahwa komunikasi yang efektif terjadi apabila mempunyai pemahaman informasi yang sama antara setiap anggota kelompok dalam penerimaan informasi. Media sesungguhnya akan memberikan informasi yang sama untuk semua peserta.

Dengan media sesungguhnya, materi pembelajaran menjadi tidak terbatas, karena banyak hal diperoleh ketika pembelajarann sedang berjalan. Sehingga proses belajar dapat berlangsung secara terus menerus dan berkelanjutan. Hal tersebut juga dapat membantu proses belajar bagi petani secara aktif dalam kegiatan penyuluhan. Sejalan dengan pendapat [12] bahwa pembelajaran aktif membuat petani aktif untuk berpendapat, terjadi timbal balik antara penyuluh pertanian dengan petani, terjadi kerjasama di dalam kegiatan penyuluhan, petani menjadi disiplin dan petani pun terlibat langsung secara intelektual dan emosional dalam proses pembelajaran.

\section{Faktor-faktor yang Mempengaruhi Efektivitas Penggunaan Media Sesungguhnya}

Analisis faktor-faktor yang mempengaruhi efektivitas penggunaan media sesungguhnya dalam penyuluhan pengendalian hama dan penyakit pada tanaman jagung di Kabupaten Langkat telah dilakukan. Dengan menggunakan SPSS telah diperoleh koefisien - koefisien model regresi seperti yang disajikan pada Tabel 7 ..

Tabel 7. Koefisien - Koefisien Model Regresi

\begin{tabular}{clcc}
\hline No. & \multicolumn{1}{c}{ Variabel } & Koefisien Regresi & t- hitung \\
\hline 1. & Komunikasi (X1) & 1,113 & $5,149 *$ \\
2. & Karakteristik Petani (X2) & 0,693 & $3,855^{*}$ \\
3. & Lingkungan (X3) & $-0,191$ & $-0,597 \mathrm{tn}$ \\
4. & Sarana Prasarana (X4) & 0,121 & $0,514 \mathrm{tn}$ \\
5. & Biaya (X5) & 0,656 & $3,875^{*}$ \\
& $\mathrm{R}^{2} \quad$ F-tabel $=2,37$ \\
& F-hitung $=0,88$ & T-tabel $=2,001$ (Kesalahan 5\%) \\
& Konstanta $=0,446$ & \\
\hline Keterangan: tn $=$ tidak nyata pada tingkat kesalahan 5\% & \\
& $*$ nyata pada tingkat kesalahan 5\%
\end{tabular}

Pada Tabel 7, dapat dilihat bahwa Koefisien Determinasi $\left(\mathrm{R}^{2}\right)$ yang diperoleh adalah sebesar 0,88 . Hal ini memberi arti bahwa $88 \%$, bahwa tingkat efektifitas penggunaan media sesungguhnya secara simultan dapat dijelaskan oleh faktor-faktor, yaitu Komunikasi (X1), Karakteristik Petani (X2), Lingkungan (X3), Sarana Prasarana (X4), dan Biaya (X5).
Sementara $16 \%$ lainnya dipengaruhi variabel lain yang tidak diketahui dalam penelitian ini.

Pengaruh variabel independen secara bersama-sama terhadap efektivitas penggunaan media sesungguhnya dalam penyuluhan pengendalian hama dan penyakit pada tanaman jagung di Kabupaten Langkat Provinsi Sumatera Utara digunakan uji F. Berdasarkan uji $F$ 
diperoleh $\mathrm{F}$ hitung $(85,407)$ lebih besar dari Ftabel $(2,37)$ pada tingkat kesalahan $5 \%$ berarti variabel independen secara bersama-sama berpengaruh nyata terhadap efektivitas penggunaan media sesungguhnya dalam Penyuluhan Pengendalian Hama dan Penyakit Pada Tanaman Jagung. Dengan demikian dapat dinyatakan, bahwa Efektivitas Penggunaan Media Sesungguhnya dalam Penyuluhan dipengaruhi oleh Komunikasi (X1), Karakteristik Petani (X2), Lingkungan (X3), Sarana Prasarana (X4) dan Biaya (X5).

Adapun pengaruh dari masing-masing variabel independen terhadap efektivitas penggunaan media sesungguhnya dalam penyuluhan pengendalian hama dan penyakit pada tanaman jagung di kabupaten Langkat dijelaskan pada sebagai berikut.

\section{Komunikasi}

Hasil analisis statistik menunjukkan bahwa nilai koefisien regresi faktor komunikasi adalah 1,113 dengan nilai t-hitung $(5,149)$ lebih besar dari t-tabel $(2,001)$ pada tingkat kesalahan $5 \%$. Hal menunjukkan bahwa variabel Komunikasi (X1) berpengaruh sangat nyata terhadap efektivitas penggunaan media.

Komunikasi sangat mempengaruhi efektivitas penggunaan media sesungguhnya dalam penyuluhan pengendalian hama dan penyakit pada tanaman jagung karena materi penyuluhan lebih mudah diterima petani. Komunikasi yang dilakukan penyuluh lewat media sesungguhnya dirasakan oleh petani lebih efektif. Hal ini karena komunikasi yang dilakukan penyuluh mengarah kepada satu tujuan yaitu fokus pada objek materi yang disampaikan melalui penggunaan media sesungguhnya yang berfungsi sebagai media komunikasi. Menurut [13], media komunikasi adalah semua sarana yang dipergunakan untuk memproduksi, mereproduksi, mendistribusikan atau menyebarkan dan menyampaikan informasi. Beberapa fungsi media komunikasi menurut [10] adalah untuk: a) Efektifitas: media komunikasi sebagai sarana untuk mempermudah dalam penyampaian informasi; b) Efisiensi: media komunikasi sebagai sarana untuk mempercepat dalam penyampaian informasi; c) Konkrit: media komunikasi sebagai sarana untuk membantu mempercepat isi pesan yang mempunyai sifat abstrak; dan d). Motivatif: media komunikasi sebagai sarana agar lebih semangat melakukan komunikasi.
Petani melihat secara langsung objek masalah yang dihadapi, yaitu hama dan penyakit yang menyerang tanaman jagung sehingga bentuk hama penyakit diketahui. Demikian juga cara mengatasi pengendalian hama penyakit tersebut dapat dilihat secara langsung bahan dan alatnya. Penggunaan media sesungguhnya dalam penyuluhan dapat menyamakan persepsi petani sehingga komunikasi lebih efektif. Benda yang dilihat atau bahan yang digunakan dalam pengendalian hama penyakit secara bersama dirasakan oleh petani. Menurut [14], bahwa agen penyuluhan dapat memanfaatkan berbagai cara untuk membantu petani agar tujuan dapat tercapai seperti mendorong untuk tukar-menukar informasi dengan rekan petani serta memberi nasihat guna menyadarkannya tentang suatu masalah.

Demikian juga dengan pengertian penyampaian materi dan objek masalah dirasakan sama. Pengetahuan dan penjelasan terhadap materi penyuluhan pertanian sama diterimanya. Selain itu daya ingat petani lebih lama terhadap materi yang disampaikan. Memori ingatan petani jauh lebih lama ketimbang hanya teori tanpa melihat langsung benda yang sesungguhnya. Maka pentingnya sebuah komunikasi yang akurat dan baik sehingga apabila kesusksesan komunikasi tidak dapat diwujudkan maka akan menimbulkan hambatan bagi komunikator dan komunikannya [15].

\section{Karakteristik Petani}

Hasil analisis statistik menunjukkan bahwa variabel Karakteristik Petani (X2) berpengaruh sangat nyata terhadap efektivitas penggunaan media sesungguhnya dalam penyuluhan pengendalian hama dan penyakit pada tanaman jagung di Kabupaten Langkat. Hal ini ditunjukkan oleh nilai t-hitung 3,855 lebih besar dari t-tabel $(2,001)$ pada tingkat kesalahan 5\%. Berdasarkan [16] bahwa karakteristik petani berkaitan dengan penggunaan media penyuluhan.

Pengaruh sangat nyata variabel karakteristik petani tersebut dikarenakan: 1) umur petani yang berkisar antara 40 - 50 tahun; 2) pendidikannya mendukung; 3) pengalaman bertani dalam mengikuti penyuluhan; 4) kepemilikan luas lahan petani, dan 5) kesamaan latar belakang menjadi petani.

Karakteristik petani berpengaruh sangat nyata terhadap efektivitas penggunaan media 
sesungguhnya karena umur petani berkisar antara 40 - 50 tahun. Petani yang sudah berumur biasanya memiliki penglihatan yang sudah menurun. Dengan menggunakan media sesungguhnya, maka petani akan lebih jelas dan memudahkan petani untuk memahami materi yang diberikan.

Pendidikan yang dimiliki petani responden dalam kategori tinggi yaitu tingkat SLTA dan sarjana $62,5 \%$. Pendidikan yang dimiliki petani dapat meningkatkan pengetahuan dan kemampuannya dalam melihat media sesungguhnya seperti hama atau penyakit tanaman. Petani bisa mengamati dan menjelaskan apa yang dilihat serta dapat disampaikan kepada petani lainnya dalam penyebaran informasi. Sejalan dengan pendapat [17], bahwa tanpa pengetahuan seseorang tidak mempunyai dasar untuk mengambil keputusan dan menentukan tindakan terhadap masalah yang dihadapi.

Petani yang sering mengikuti penyuluhan akan mempunyai pengalaman dalam mendengarkan atau menerima pesan materi yang disampaikan penyuluh pertanian. Penyuluh yang menggunakan media sesungguhnya dalam penyuluhan dirasakan lebih mudah untuk diterima dibandingkan media lainnya. Hasil penelitian ini sejalan dengan penelitian [18] bahwa semakin berpengalaman petani dalam berusaha tani, mereka semakin paham seluk beluk usahataninya.

Demikian pula petani yang memiliki lahan yang luas lebih cenderung mengikuti penyuluhan karena dapat menambah pengetahuan dan kemampuannya dalam mengelola usahatani sehingga produksi yang dihasilkan dari lahannya yang luas lebih tinggi dari sebelumnya. Menurut [19], bahwa kepemilikan lahan yang luas cenderung tingkat adopsinya lebih tinggi.

\section{Lingkungan}

Hasil analisis statistik menunjukkan bahwa nilai t-hitung $(-0,597)$ lebih kecil dari t-tabel $(2,001)$ pada tingkat kesalahan 5\%. Hal ini berarti bahwa variabel Lingkungan (X3) berpengaruh tidak nyata terhadap efektivitas penggunaan media sesungguhnya dalam penyuluhan pengendalian hama dan penyakit pada tanaman jagung di kabupaten langkat.

Variabel lingkungan berpengaruh tidak nyata terhadap efektivitas penggunaan media sesungguhnya karena, yaitu a) lahan usahatani dan sekitarnya mendukung penyediaan bahan penyuluhan menggunakan media sesungguhnya; b) penggunaan media sesungguhnya tidak harus dilahan usahatani saja; c) kondisi sasaran ; dan d) tidak bertentangan dengan kebudayaan setempat.

Lingkungan lokasi penyuluhan maupun lahan sekitarnya menyediakan bahan media penyuluhan. Penggunaan media sesungguhnya saat penyuluhan pengendalian hama dan penyakit sesuai kondisi sasaran penyuluhan juga. Petani menganggap bahwa lingkungan tempat dilakukannya penyuluhan semuanya mendukung dan tidak bermasalah. Menurut [20], bahwa penyuluh lapang berperan penting tidak sekedar memperkenalkan teknologi kepada petani, melainkan juga meningkatkan kapasitas petani agar mampu secara mandiri menjalankan usaha taninya. Pada akhirnya lingkungan itu tidak berpengaruh terhadap efektivitas penggunaan media sesungguhnya dalam penyuluhan pengendalian hama dan penyakit pada tanaman jagung di Kabupaten Langkat.

\section{Sarana Prasarana}

Hasil analisis statistik menunjukkan bahwa nilai t-hitung $(0,514)$ lebih kecil dari t-tabel $(2,001)$ pada tingkat kesalahan 5\%. Hal ini berarti bahwa variabel Sarana Prasarana (X4) berpengaruh tidak nyata terhadap efektivitas penggunaan media sesungguhnya dalam penyuluhan pengendalian hama dan penyakit pada tanaman jagung di Kabupaten Langkat.

Variabel Sarana Prasarana (X4) berpengaruh tidak nyata terhadap efektivitas penggunaan media sesungguhnya karena: a) tidak memerlukan peralatan penyuluhan yang harus berstandar baik; b) tidak memerlukan peralatan penyuluhan pertanian; c) tidak membutuhkan ketersediaan transpostasi; d) tidak memerlukan sarana prasarana yang mudah dijangkau sasaran penyuluhan; dan e) sarana prasarana penyuluhan tidak dipandang manfaatnya oleh petani.

Sarana prasarana berpengaruh tidak nyata karena sudah tersedia dilahan pertanian dan sudah berstandar baik. Peralatan pun tidak dibutuhkan saat penyuluhan berlangsung apabila menggunakan media. Tidak membutuhkan transportasi untuk membawa media penyuluhan ke lapangan atau lokasi penyuluhan. Artinya ada atau tidak sarana prasarana tidak mempengaruhi keefektifan penggunaan media sesungguhnya dalam penyuluhan pengendalian hama dan penyakit pada tanaman jagung. 
Tetapi ada satu hal yang kurang di lahan usaha tani jagung yaitu belum adanya papan informasi yang dapat digunakan oleh petani sebagai panduan dalam mengamati serangan hama dan penyakit dengan memanfaatkan media sesungguhnya yang terdapat di lahan jagung. Hal ini menyebabkan petani sering lalai dalam mengamati serangan hama dan peyakit pada tanaman jagung. Menurut [20] kurangnya tingkat ketersediaan informasi ditandai dengan relevansi informasi, ketepatan waktu informasi dan kemudahan mendapatkan informasi yang disediakan oleh penyuluh.

\section{Biaya}

Hasil analisis statistik menunjukkan bahwa variabel Biaya (X5) berpengaruh sangat nyata terhadap efektivitas penggunaan media sesungguhnya dalam penyuluhan pengendalian hama dan penyakit pada tanaman jagung di Kabupaten Langkat. Hal ini ditunjukkan oleh nilai t-hitung 3,875 lebih besar dari t-tabel $(2,001)$ pada tingkat kesalahan 5\%.

Pengaruh sangat nyata variabel Biaya (X5) terhadap efektivitas penggunaan media sesungguhnya dikarenakan: a) dapat mengurangi resiko kerugian dalam penyuluhan; b) biaya yang dikeluarkan murah; c) lebih ekonomis karena bahan mudah diperoleh; d) tidak mempengaruhi dalam pencapaian tujuan penyuluhan; dan e) tidak mengurangi mutu media sesungguhnya yang digunakan dalam penyuluhan.

Biaya mempengaruhi efektivitas penggunaan media sesungguhnya, karena dapat mengurangi resiko kerugian dalam penyuluhan. Bahan dan alat dalam membuat media penyuluhan oleh penyuluh tidak diperlukan karena sudah ada di sekitar lokasi penyuluhan. Penyelenggara penyuluhan sebagai penyedia sarana dan prasara penyuluh tidak banyak mengeluarkan biaya bila menggunakan media sesungguhnya, apalagi bagi kabupaten yang memiliki banyak desa atau kecamatan. Hanya yang perlu diperhatikan disini adalah bagaimana penyuluh dapat mengelola potensi sumberdaya yang ada di wilayah kerjanya agar bisa memanfaatkan sumberdaya tersebut baik sumberdaya alam atau manusia untuk membuat media penyuluhan.

Pengertian efektifitas secara umum menunjukkan sampai seberapa jauh tercapainya suatu tujuan yang terlebih dahulu ditentukan. Lebih lanjut, [21] menjelaskan efektifitas adalah suatu ukuran yang menyatakan seberapa jauh target (kuantitas, kualitas dan waktu) telah tercapai. Dimana makin besar persentase target yang dicapai, makin tinggi efektifitasnya.

Meskipun biaya yang digunakan murah bahkan tidak ada tetapi tidak mengurangi mutu media sesungguhnya yang digunakan dalam penyuluhan. Mutu media penting dalam membuat media, hal ini karena media yang dibuat memiliki kriteria seperti gambar jelas, tulisan jelas, gambar tidak mengandung makna ganda, dan lain-lain. Sasaran penyuluhan atau petani memiliki keterbatasan seperti mata yang rabun, pengetahuan yang berbeda antar sesama petani, dan pendidikan berbeda. Tetapi dengan menggunakan media sesungguhnya tidak mengurangi mutunya. Petani langsung dapat melihatnya dan merasakannya.

\section{KESIMPULAN}

Berdasarkan hasil penelitian ini dapat disimpulkan:

a. Tingkat efektivitas penggunaan media sesungguhnya dalam penyuluhan pengendalian hama dan penyakit pada tanaman jagung di Kabupaten Langkat sangat efektif dengan nilai sebesar $86,14 \%$;

b. Faktor - faktor Komunikasi (X1), Karakteristik Petani (X2), Lingkungan (X3), Sarana Prasarana (X4) dan Biaya (X5) secara simultan berpengaruh nyata terhadap efektivitas penggunaan media sesungguhnya dalam penyuluhan pengendalian hama dan penyakit pada tanaman jagung di Kabupaten Langkat. Sedangkan secara parsial faktor-faktor Komunikasi (X1), Karakteristik Petani (X2) dan Biaya (X5) berpengaruh secara signifikan, dan faktor - faktor lingkungan (X3) dan Sarana dan Prasarana (X4) secara nyata tidak berpengaruh.

\section{DAFTAR PUSTAKA}

[1] Dinas Pertanianian Kabupaten Langkat. 2019. Luas Lahan Jagung di Kabupaten Langkat.

[2] Nugraha, Agah dan Sundayana, Rostina. 2014. Penggunaan Alat Peraga Sebagai Upaya Untuk Meningkatkan Prestasi Belajar Dalam Memahami Konsep Bentuk Aljabar Pada Siswa Kelas VIII Di Smpn 2 Pasirwangi. Jurnal Pendidikan Matematika. 3 (3) :133-141. 
[3] Sugiyono. 2017. Metode Penelitian Pendidikan. Cetakan ke-12. Bandung. Alfabeta.

[4] Pasaribu, L. 2018. Pengaruh Media Audiovisual Terhadap Keberhasilan Kegiatan Penyuluhan Pertanian Di Desa Tanjung Merahe Kecamatan Selesai Kabupaten Langkat Provinsi Sumatera Utara. Jurnal Agrica Ekstensia. 12 (1) : 37-44.

[5] Leilani, Ani, et. al. 2015. Efektivitas Penggunaan Media Penyuluhan. Jurnal Penyuluhan Kelautan dan Perikanan Indonesia. 9 (1): 43 - 54.

[6] Imran, NA, et al. 2019. Metode Penyuluhan Pertanian Dalam Meningkatkan Pengetahuan Dan Keterampilan Petani (Studi Kasus Di Kecamatan Maros Baru Kabupaten Maros). Jurnal Agrisep. 18 (2) : 291

[7] Sugiyono. 2014. Metode Penelitian Pendidikan Pendekatan Kuantitatif, Kualitatif, dan $R \& D$. Bandung. Alfabeta.

[8] Noor. 2011. Metodologi Penelitian: Skripsi, Tesis, Disertasi, dan Karya Ilmiah. Jakarta. Kencana Prenada Media Group.

[9] Manyamsari dan Mujiburrahmad. 2014. Karakteristik Petani dan Hubungannya Dengan Kompetensi Petani Lahan Sempit, Kasus: Di Desa Sinar Sari Kecamatan Dramaga Kab. Bogor Jawa Barat. Jurnal Agrisep. 15 (2)

[10] Umyati, S dan Sendjaja, T. 2019. Faktor Faktor yang Mempengaruhi Petani Dalam Pengalokasian Dana Ganti Rugi Konversi Lahan Pertanian (Suatu Kasus Konversi Lahan Sawah untuk Pembangunan Bandara Internasional Jawa Barat di Kecamatan Kertajati Kabupaten Majalengka). Jurnal Agribisnis dan Sosial Ekonomi Pertanian UNPAD. 4 (1) : 624

[11] Alif Muhammad. 2017. Partisipasi Petani Dalam Komunikasi Penyuluhan, Studi Pada Kelompok Tani Sumber Murni Kelurahan Landasan Ulin Utara Kecamatan Landasan Ulin Kota Banjarbaru. Program Studi Ilmu Komunikasi. Universitas Lambung Mangkurat.

DOI: https://doi.org/10.55127/ae.v15i2.92
[12] Rusdy dan Sunartomo. 2013. Proses Komunikasi Dalam Penyuluhan Pertanian Program System Of Rice Intensification (SRI). Program Studi Agribisnis Fakultas Pertanian Universitas Jember.

[13] Sulistyani. 2012. Peningkatan Keaktifan Belajar Siswa Dengan Penerapan Metode Guided Note Taking Pada Mata Diklat Memilih Bahan Baku Busana Di SMK Negeri 4 Yogyakarta. Universitas Negeri Yogyakarta.

[14] Syaifudin, F. 2016. Media Komunikasi Mahasiswa Dalam meningkatkan Prestasi Studi: Studi Kasus Pada Mahasiswa Fakultas Dakwah Dan Komunikasi Universitas Islam Negeri Sunan Ampel Surabaya. UIN Sunan Ampel Surabaya.

[15] Setiawan APIG. 2015. Kajian Analitik Masalah-masalah Penyuluhan Pertanian. Jurnal Penyuluhan. 1(1): 57-61.

[16] Falletehan, Dama Paundra. 2011. Hambatan Komunikasi Dalam Film "YoursTruly". https://jurnal.usu.ac.id/index.php/flow / article/viewFile/12799/5556 Diakses 10 Januari 2020.

[17] Effendy, L. 2017. Merancang Pengkajian Penyuluhan. Bahan Ajar STPP Bogor.

[18] Muchtar K, Purnaningsih N, Susanto D. 2014. Komunikasi Partisipatif pada Sekolah Lapangan Pengelolaan Tanaman Terpadu (SL-PTT). Jurnal Komunikasi Pembangunan. 12 (2): 114.

[19] Wangke WM, Olfie B, Suzana L.2016. Adopsi Petani Terhadap Inovasi Tanaman Padi Sawah Organik di Desa Molompar Kecamatan Tombatu Timur, Kabupaten Minahasa Tenggara. Jurnal Agri Sosio Ekonomi Unsrat. 12 (2) : 143- 152.

[20] Ruhimat, IS. 2014. Faktor-faktor untuk Peningkatan Kemandirian Petani dalam Pengelolaan Hutan Rakyat: Studi Kasus di Desa Ranggang Kabupaten Tanah Laut Kalimantan Sekatan. Jurnal Penelitian Sosial dan Ekonomi Kehutanan. 11(3): 237 - 249.

[21] Rizky, S. 2011. Konsep Dasar Rekayasa Perangkat Lunak. Prestasi Pustaka. Jakarta. 